\title{
Production of 5-Hydroxymethylfurfural from Chitin Biomass: A Review
}

\author{
Dan Zhou ${ }^{1}$, Dongsheng Shen ${ }^{1}$, Wenjing Lu ${ }^{2}$, Tao Song ${ }^{3}$, Meizhen Wang ${ }^{1}$, Huajun Feng ${ }^{1}$, \\ Jiali Shentu ${ }^{1}$ and Yuyang Long ${ }^{1, *}$ \\ 1 Zhejiang Provincial Key Laboratory of Solid Waste Treatment and Recycling, Analysis and Testing Center, \\ School of Environmental Science and Engineering, Zhejiang Gongshang University, Hangzhou 310012, \\ China; dddddd926@163.com (D.Z.); shends@zju.edu.cn (D.S.); wmzyy@163.com (M.W.); \\ fenghuajun2000@163.com (H.F.); shentuj1@mail.zjgsu.edu.cn (J.S.) \\ 2 School of Environment, Tsinghua University, Beijing 100084, China; luwenjing@tsinghua.edu.cn \\ 3 School of Energy and Mechanical Engineering, Nanjing Normal University, Nanjing 210023, China; \\ tsong@njnu.edu.cn \\ * Correspondence: longyy@zjgsu.edu.cn
}

Academic Editor: Michela Signoretto

Received: 31 December 2019; Accepted: 25 January 2020; Published: 27 January 2020

\begin{abstract}
Chitin biomass, a rich renewable resource, is the second most abundant natural polysaccharide after cellulose. Conversion of chitin biomass to high value-added chemicals can play a significant role in alleviating the global energy crisis and environmental pollution. In this review, the recent achievements in converting chitin biomass to high-value chemicals, such as 5-hydroxymethylfurfural (HMF), under different conditions using chitin, chitosan, glucosamine, and $\mathrm{N}$-acetylglucosamine as raw materials are summarized. Related research on pretreatment technology of chitin biomass is also discussed. New approaches for transformation of chitin biomass to HMF are also proposed. This review promotes the development of industrial technologies for degradation of chitin biomass and preparation of HMF. It also provides insight into a sustainable future in terms of renewable resources.
\end{abstract}

Keywords: 5-hydroxymethylfurfural; chitin biomass; pretreatment; chitosan; degradation; biorefinery

\section{Introduction}

Investigation of green renewable energy has gradually become a main research direction in recent years. As a substitute for fossil fuel, biomass is a potential renewable resource for future production of fuels and high value chemical products owing to the vast number of organic chemical products that can be potentially manufactured from biomass $[1,2]$. Biomass includes plant fibers, such as lignocellulose, and animal fibers, such as chitin [3]. Lignocellulosic materials have been widely investigated [4,5]. Chitin is the world's second most abundant biopolymer. However, chitin biomass transformation is still in the initial stage. Chitin biomass includes raw materials, such as crustacean shells, and purified chitin, chitosan, and its corresponding monomers ( $\mathrm{N}$-acetylglucosamine (GlcNAc) and glucosamine $\left.\left(\mathrm{GlcNH}_{2}\right)\right)$ and derivatives. Chitin widely exists in crustacean shells, insect skeletons, fungi, etc. With the rapid growth of the fishery industry, which is the main source of chitin biomass, global fishery production has become well above 100 million tons per year with a large amount of crustacean wastes. An estimated 6-8 million tons of shell waste from crustaceans is produced annually [6]. Generally, most crustacean waste is directly disposed of in landfills without utilization which not only poses environmental issues, but it is also a waste of resources [7]. Valorization of shell waste will have both ecological and economic benefits. 
Determining the potential value of chitin biomass is in accordance with the concept of green chemistry. There is a growing interest in chitin biomass, and conversion of chitin biomass to high value-added compounds has become a new research hotspot. In recent years, the concept of shell biorefinery has been proposed [3,8,9]. Chitin biomass should be fully utilized like cellulose biomass by converting it to high value chemicals (Figure 1). Among the various high-value chemicals, 5-hydroxymethylfurfural (HMF) is one of the most promising value-added platform compounds [10]. 5-Hydroxymethylfurfural, which is highly chemically reactive, can be prepared by oxidation, hydrogenation, etc. It has huge market potential which can be used to produce 2,5-furandialdehyde, 2,5-furandicarboxylic acid, levulinic acid (LA), and other high value-added chemicals and liquid fuels. Chitin biomass is an ideal raw material for preparation of HMF. Tapping the potential of chitin biomass to obtain the high value-added platform compound HMF is an important way to improve the output of waste resources, and it is expected to lead to new directions for high-value utilization of chitin biomass.

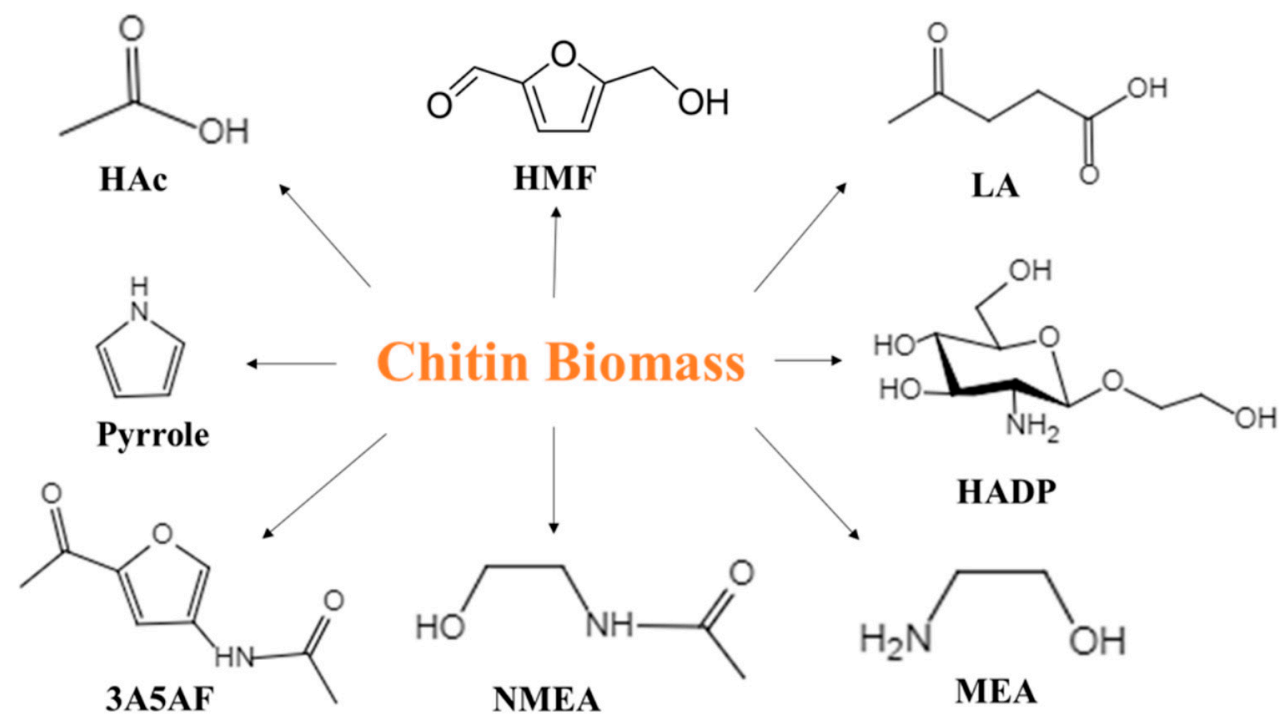

Figure 1. An overview of chitin biomass conversion into various chemicals. HAc, acetic acid; HMF, hydroxymethyl furfural; LA, levulinic acid; HADP, hydroxyethyl-2-amino-2-deoxyhexopyranoside; 3A5AF, 3-acetamido-5-acetylfuran; NMEA, N-acetylmonoethanolamine; MEA, monoethanolamine.

This paper reviews the recent related research progress in the conversion of chitin biomass to HMF and summarizes the methods and pathways during the conversion process under different conditions. Finally, the potential future research directions are also proposed.

\section{Structure of Chitin Biomass}

Chitin biomass includes raw materials, such as shrimp and crab shells, and purified chitin, chitosan, and its corresponding monomers (GlcNAc and $\mathrm{GlcNH}_{2}$ ) and derivatives [11]. Chitin widely exists in nature including in the shells of insects and crustaceans (e.g., shrimps and crabs). The skeletal shells of mollusks and cell walls of certain algae and fungi also contain chitin. It is the most abundant natural nitrogen-containing polymer polysaccharide in the world, and it is also an important nitrogen source for typical earth and marine organisms.

Chitin is a linear polymer polysaccharide formed by condensing $\mathrm{N}$-acetylglucosamine with $\beta$-1,4-glucoside bonds, and the relative molecular weight of chitin ranges from hundreds of thousands to millions DA. The chemical structure of chitin is basically the same as lignocellulose. The difference between them is that the functional group at the $\mathrm{C}_{2}$ position of cellulose is the hydroxyl group $(-\mathrm{OH})$ while that of chitin is the acetylamino group $\left(\mathrm{CH}_{3} \mathrm{CONH}-\right)$, as is shown in Figure 2. Therefore, chitin 
is sometimes referred to as animal cellulose. The monomer of chitin is GlcNAc which can be obtained from chitin by hydrolysis with concentrated hydrochloric acid $(\mathrm{HCl})$ or sulfuric acid $\left(\mathrm{H}_{2} \mathrm{SO}_{4}\right)$ or the enzymatic hydrolysis.

The product obtained after removing most of the $N$-acetyl groups from the sugar group in the chitin structure is called chitosan which is also known as deacetylated chitin. The deacetylated products that have a degree of deacetylation (DD) greater than $60 \%$ or are soluble in dilute acid are generally called chitosan. Compared with chitin, chitosan contains less acetyl groups, more amino groups, and has higher solubility. Chitosan has great application potential because of its unique properties and physiological activities. The monomer of chitosan is $\mathrm{GlCNH}_{2}$ which is the compound obtained by replacing $-\mathrm{OH}$ at the $\mathrm{C}_{2}$ position of glucose with $-\mathrm{NH}_{2}$, as is shown in Figure 2. It can also exist in various forms in living organism polysaccharides and conjugated polysaccharides.

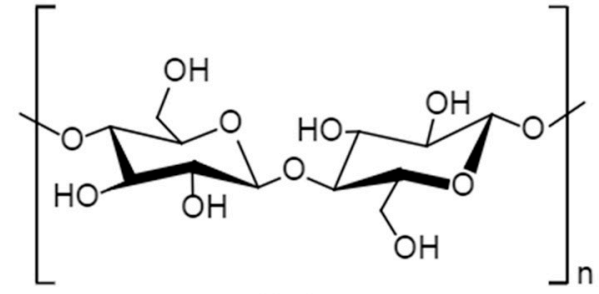

cellulose

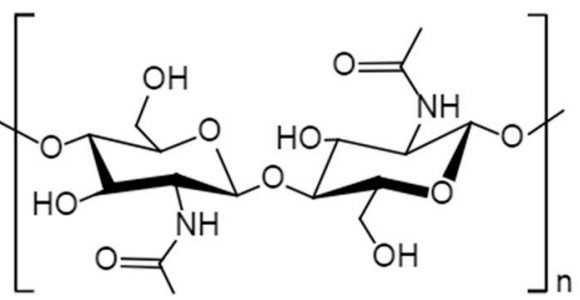

chitin

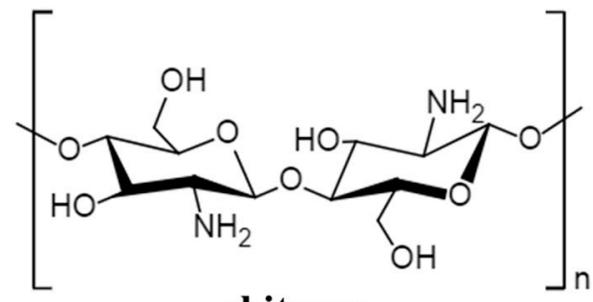

chitosan<smiles>OC[C@H]1O[C@H](O)[C@@H](O)[C@H](O)[C@H]1O</smiles>

glucose<smiles>CC(=O)N[C@@H]1O[C@H](O)[C@H](O)[C@H](O)[C@H]1O</smiles>

GIcNAc

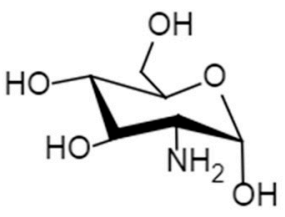

GlcNH $_{2}$

Figure 2. Chemical structure of cellulose, chitin, and chitosan and their corresponding monomers.

\section{Chitin Biomass Pretreatment Techniques}

As the main source of chitin, crustacean shells normally contain $20-50 \%$ calcium carbonate, $20-40 \%$ protein, and $15-40 \%$ chitin. The chitin in crustacean shells is embedded and solidified by a mineral-protein matrix [12]. Therefore, it is not easy to directly transform chitin biomass to HMF. Some researchers have found that pretreatment of chitin biomass before the reaction, such as transforming chitin or chitosan to high-purity chitin or low-molecular-weight chitosan, can effectively improve the HMF yield. The conversion process of chitin biomass to HMF is shown in Figure 3. The chitosan reaction activity increases with decreasing molecular weight, and conversion to HMF is also enhanced. Through various pretreatment methods, demineralization and deproteinization are required to remove $\mathrm{CaCO}_{3}$ and protein in chitin biomass in order to prepare purity chitin. Furthermore, the acetyl group is removed to convert chitin into low-molecular-weight chitosan and even its monomer by deacetylation. These are conducive to the progress of the reaction. Thus, pretreatment provides favorable conditions for conversion of chitin biomass to HMF. Pretreatment methods for chitin biomass are mainly divided 
into chemical methods, biological methods, and physical-assisted methods. The principles for choosing a pretreatment method are to minimize the energy consumption and provide good compatibility with the following process.

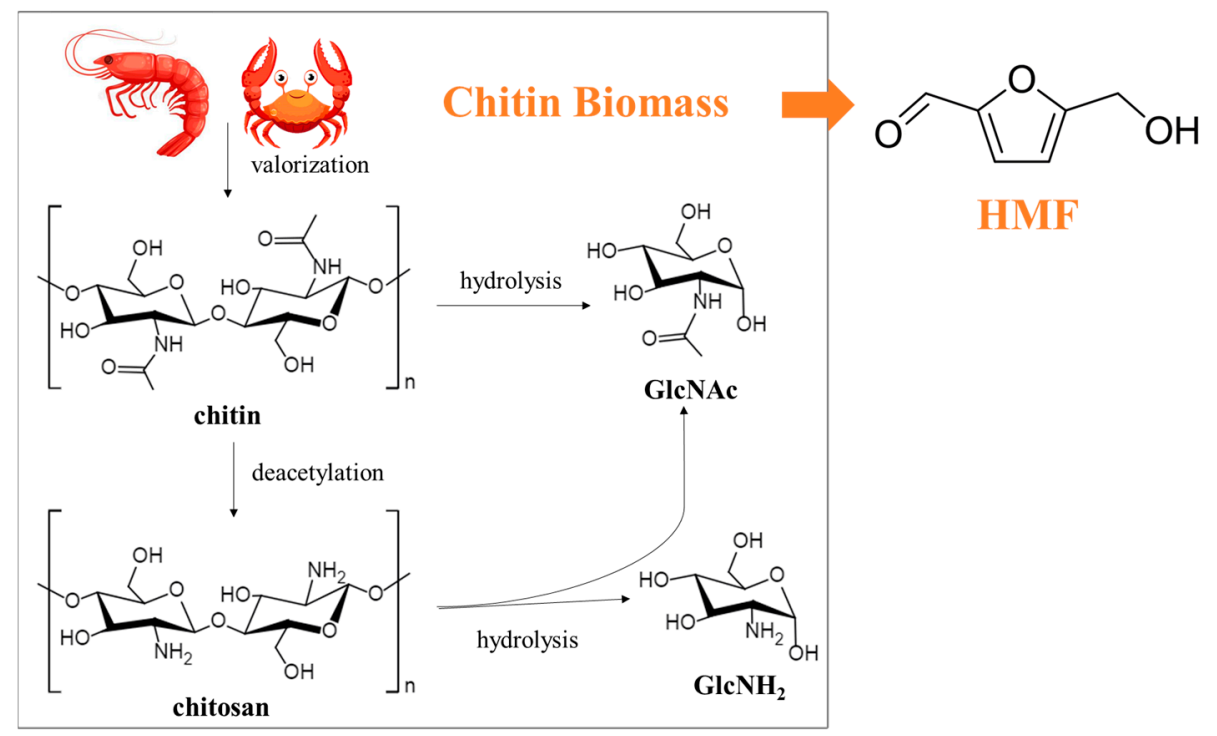

Figure 3. Production of HMF from chitin biomass.

\subsection{Chemical and Biological Pretreatment}

Traditional chemical methods usually use dilute $\mathrm{HCl}$ solution $(0.3-2 \mathrm{M})$ for demineralization. It consists of eliminating $\mathrm{CaCO}_{3}$ and $\mathrm{CaCl}_{2}$ which constitute the main inorganic compounds of crustacean shells. During the digestion reaction, the emission of $\mathrm{CO}_{2}$ gas indicates the content of mineral materials. Furthermore, deproteinization is performed using alkaline treatment using dilute sodium hydroxide $(\mathrm{NaOH})$ solution $(0.5-4 \mathrm{M})$ to remove proteins. The product obtained is designated as purified chitin. Extraction of chitosan usually requires a deacetylation process in a high-concentration alkali solution at high temperature. Despite the many disadvantages of chemical methods, the extraction time is short which makes it the most commonly used commercial treatment. However, these methods inevitably generate a large amount of corrosive acid-base wastewater which may cause serious environmental problems $[13,14]$.

Biological treatments, such as enzyme reaction and microbial fermentation, offer an alternative way to extract chitin and chitosan $[15,16]$. For instance, lactic-acid-producing bacteria and proteases from bacteria have been used for the demineralization and deproteinization steps, respectively. Chitin deacetylation have been performed by enzymatic methods. Using these methods, the above problem of environmental pollution can be avoided. Moreover, the molecular weight and crystallinity of the obtained chitin are higher than those of chemically prepared chitin [17]. However, these biological processes are insufficient to remove the minerals and proteins from crustacean shells [18]. In addition, long fermentation cycles and expensive enzymes prevent commercial application of these methods.

As a more sustainable alternative to volatile organic solvents, ionic liquids (ILs) such as 1-allyl-3-methylimidazolium bromide and 1-ethyl-3-methylimidazolium acetate have been used for direct extraction of chitin from crustacean shells $[18,19]$. Ionic liquids are considered to be promising solvents for chitin production because of their low vapor pressures, non-flammability, and excellent solubilities [20]. They can also promote the deacetylation process [21]. Nevertheless, ILs have some drawbacks, such as high cost, toxicity, and non-biodegradability, which significantly limit their use in various applications [22,23]. Therefore, a more economic, efficient, and eco-friendly technique is desirable for extraction of chitin and chitosan. 
Deep eutectic solvents (DESs) are a greener alternative to conventional ILs. They are obtained by mixing a hydrogen bond acceptor and a hydrogen bond donor that are capable of self-association through hydrogen-bonding interactions to form a eutectic with a lower melting point than each individual component [24,25]. Compared with traditional ILs, DESs possess more advantages such as low toxicity, low cost, ease of syntheses, biodegradability, and negligible volatility. Owing to these properties, DESs have various applications including organic synthesis, dissolution media, extraction processes, and materials chemistry [26]. Some DESs prepared from choline chloride and four organic acids have been evaluated for the extraction of chitin from lobster shell; among them, the purity of chitin extracted with choline chloride-malonic acid was the highest $[27,28]$. Furthermore, natural DESs (NADESs), which are composed of natural compounds, are sustainable, non-toxic, and biodegradable. Choline chloride-malic acid has been used to extract chitin, and most of the minerals and proteins in shrimp shells can be removed under microwave-assisted conditions. The NADESs possess better properties during extraction than ILs and DESs [29]. However, the ideal type of DES for biomass conversion is still unclear. In addition, there is a lack of product diversity in the downstream conversion process of DES-fractionated products and further research is needed [30].

Some researchers are already investigating the use of natural resources, such as glycerol, as the reaction solvent for extraction of chitin and chitosan as is shown in Table 1. Glycerol, a by-product of biodiesel production, is readily available, non-toxic, inexpensive, biodegradable, and has deproteinization ability. Recent studies have shown that acids are capable of deproteinizing chitin during extraction of chitin from crustacean shells [31]. Therefore, some researchers have combined an acid and glycerol to produce chitin. Hong et al. [32] used a glycerol and $\mathrm{HCl}$ co-solvent to achieve demineralization and deproteinization at low temperature for one-step production of chitin from lobster shells. Although $\mathrm{HCl}$ was used in this method, the acid amount was lower than that required for the conventional method. Devi et al. [33] used citric acid instead of $\mathrm{HCl}$ to directly demineralize and deproteinize chitin after preliminary deproteinization by hot glycerol pretreatment. Plasticization of prawn shell waste by glycerol enabled uniform heat transfer, and it could possibly be the driving force for thermal depolymerization of proteins in the absence of acid or base catalysts. In addition, the glycerol used in the pretreatment was effectively reused and recycled. Using citric acid is also more environmentally friendly than using $\mathrm{HCl}$. Using glycerol as the reaction solvent for deacetylation of chitin could realize deacetylation of chitin with low $\mathrm{NaOH}$ concentration and provide an efficient and green process for chitosan extraction from chitin [34].

Table 1. Glycerol as the reaction solvent for extraction of chitin and chitosan.

\begin{tabular}{cccc}
\hline Natural Resource & Reaction Solvent & Product & Condition \\
\hline \multirow{2}{*}{ glycerol } & hot glycerol & chitin & - \\
& Glycerol $+5-7 \% \mathrm{HCl}$ & $55 \mathrm{kDa}$ chitin & $7 \% \mathrm{HCl}, 120^{\circ} \mathrm{C}, 2 \mathrm{~h}$ \\
& Glycerol $+30 \% \mathrm{NaOH}$ & chitosan & $180{ }^{\circ} \mathrm{C}, 12 \mathrm{~h}$, liquid-solid $=40$ \\
\hline
\end{tabular}

Recently, Yang et al. [35] developed a new economical and feasible shrimp shell fractionation method using hot water deproteinization and carbonic acid demineralization to extract high-value chitin from crustacean shells such as shrimp shells. The proteins were partially hydrolyzed and fully solubilized in water at high temperature. The $\mathrm{CaCO}_{3}$ was then dissolved under pressured $\mathrm{CO}_{2}$ in aqueous solution at room temperature. This simple and feasible method can give chitin products with high purity (>90\%) while reducing costs and waste generation.

\subsection{Physical-Assisted Pretreatment}

Because some of the above methods are time consuming and energy intensive, a wide variety of physical-assisted techniques for production of low-molecular-weight chitin or chitosan have 
been investigated such as the ultrasonic, microwave-assisted alkali, mechanochemical, and plasma treatment [36].

Some researchers have investigated ultrasonic pretreatment of chitosan which can increase the HMF yield. Other researchers have performed ultrasound-assisted deacetylation to convert both $\alpha$-chitin and $\beta$-chitin to chitosan $[37,38]$. High-intensity ultrasound irradiation strongly enhances the $N$-deacetylation reaction, favoring production of completely acid-soluble chitosan at high yield. In addition, the ultrasound-assisted deacetylation process allows preparation of unusually high molecular weight randomly deacetylated chitosan. Ultrasound-assisted extraction of chitosan can also significantly reduce the molecular weight and improve the properties of chitosan [39].

In the past decade, microwave irradiation has been widely used as a powerful tool for rapid and efficient synthesis. This new technology has replaced conventional heating using three-dimensional heating of the reaction mass $[40,41]$. Many researchers have successfully deacetylated chitin to chitosan using microwave radiation, with the DD reaching $80-95 \%$ in a few minutes and the molecular weight greatly decreasing. However, microwave deacetylation still consumes as much $\mathrm{NaOH}$ as traditional deacetylation [42-45]. El Knidri et al. [46] were the first to use microwave technology for demineralization and deproteinization. Microwave radiation was used throughout. It shortened the duration time to $1 / 16$ of that of the traditional method. The chitosan produced by microwave heating had the same DD as the traditional method (DD of chitosan produced by conventional heating $81.5 \%$ and DD of chitosan produced by microwave heating $82.7 \%$ ). Compared with conventional extraction, microwave synthesis dramatically decreases the reaction time and increases the product yield and purity by decreasing unwanted side reactions.

Mechanochemistry that uses mechanical energy to activate chemical reactions is also widely used in high value-added conversion of various barely degradable biomasses [47-49]. Chen et al. [50] achieved one-step conversion of chitin and raw shrimp shells to low-molecular-weight chitosan in the solid state by using the synergistic mechanical force and base catalysis. Ball milling significantly and simultaneously enhanced base-catalyzed depolymerization and deacetylation of chitin, giving a chitosan oligomer with $80.5 \% \mathrm{DD}$ and $7.9 \mathrm{kDa}$ molecular weight. The base usage was reduced to about $1 / 10$ of that used by traditional approaches. The synergistic effects of the mechanical and chemicals forces were crucial for simultaneous depolymerization and deacetylation. However, treatment takes about $2 \mathrm{~h}$ which is much longer than the microwave deacetylation time, so energy consumption is relatively high.

Green chemistry is an important issue in current society, and a green and feasible pretreatment method should be used for biomass conversion. An efficient green pretreatment extraction process of chitin and/or chitosan should be selected by combining reasonable pretreatment methods to realize the possibility of chitin biomass conversion to HMF. For instance, to promote the reaction, suitable green solvents, such as DESs and glycerol, can be added to the catalytic reaction system. Furthermore, physical-assisted methods can be combined with chemical or biological methods to take advantage of their respective advantages. For example, green solvents, such as DESs [51] or glycerol, could be used in microwave processes. Microwave radiation not only shortens the reaction time for extracting chitin and chitosan, but it also greatly reduces the amount of acid or alkali in the reaction with the addition of green solvents. Through efficient and green extraction of chitin and chitosan, conversion of chitin biomass to HMF can be achieved.

\section{HMF Production from Chitin Biomass}

5-Hydroxymethylfurfural has been ranked as the most valuable bio-based platform compound derived from biomass [10]. It is one of the most important high value-added compounds [52], and it is widely used in the preparation of multifunctional compounds such as fine chemicals, key pharmaceutical intermediates, functional polyesters, solvents, and liquid fuels [53]. It can be obtained by dehydration of glucose and fructose produced by hydrolysis of lignocellulose [54], as shown in Figure 4. Chitin is similar to cellulose in structure, so chitin biomass can also be converted to HMF. 
Although conversion of chitin to nitrogen-free high value-added chemical-waste nitrogen resources, production of nitrogen-free platform compounds provides more choices for the effective use of biomass, so it is easier to achieve biorefinery. Therefore, conversion of chitin biomass to HMF has important research significance.

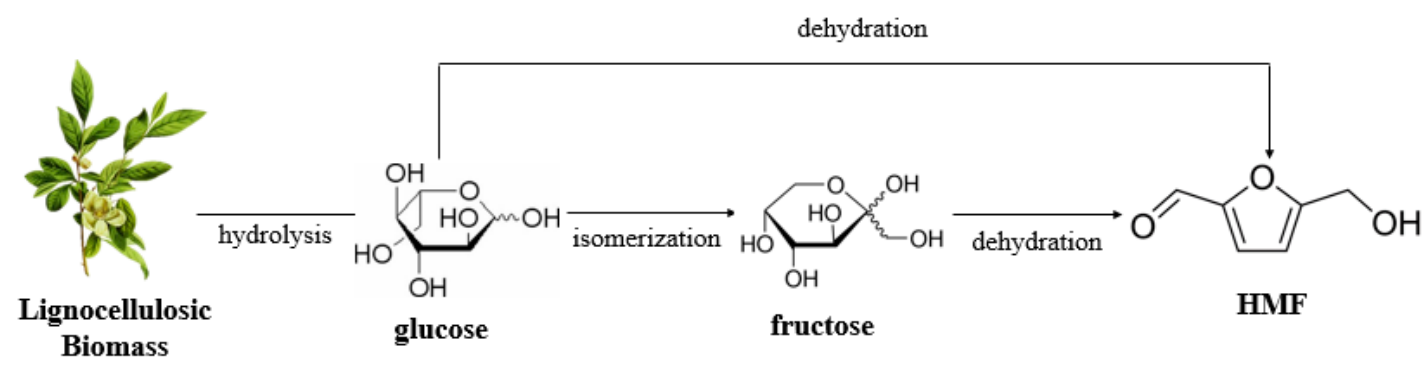

Figure 4. Production of HMF from lignocellulosic biomass.

\subsection{HMF Production from Chitin Biomass by Brønsted Acids}

Brønsted acid is a general term for molecules or ions that release protons. Common Brønsted acids (e.g., $\mathrm{HCl}, \mathrm{H}_{2} \mathrm{SO}_{4}$, and acetic acid) have low production costs, are easy to prepare, and are widely used. In early studies, $\mathrm{HCl}$ solution was usually used to catalyze degradation of chitin biomass, but only trace amounts of HMF were obtained. Omari et al. [55] used $\mathrm{HCl}$ to catalyze degradation of chitosan at $200{ }^{\circ} \mathrm{C}$ for $30 \mathrm{~min}$ under microwave heating, but they only obtained $2.2 \% \mathrm{HMF}$. Lee et al. [56] subsequently used $2.2 \% \mathrm{H}_{2} \mathrm{SO}_{4}$ instead of $\mathrm{HCl}$ to catalyze degradation of chitosan at $174{ }^{\circ} \mathrm{C}$ for $36.9 \mathrm{~min}$ and obtained 12.1\% HMF. Compared with earlier studies, this method not only gave higher yield, but it also significantly reduced the reaction temperature and acid concentration. Therefore, energy consumption and waste acid production were significantly reduced. Jeong et al. [57] also catalyzed $\mathrm{GlcNH}_{2}$ degradation under similar conditions to those mentioned above. They achieved an HMF yield of $1.8 \%$ in $5 \mathrm{~min}$, but the HMF yield decreased with time. Under similar conditions, the type and concentration of the substrate greatly affected the HMF yield. It is well known that glucose isomerizes to fructose and then dehydrates to form HMF. As with glucose, $\mathrm{GlcNH}_{2}$ in the form of pyranose first isomerizes to furanose. Subsequently, $\mathrm{GlcNH}_{2}$ removes the $\mathrm{NH}_{2}$ groups in furanose by deamination under acidic conditions. Finally, HMF is formed by dehydration and keto-enol tautomerization, and it then rehydrates to levulinic acid (LA) and formic acid. Therefore, $\mathrm{GlcNH}_{2}$ as the monomer of chitosan does not easily form HMF under the above conditions, but it has the potential to convert to LA, so the HMF yield is low.

Methanesulfonic acid is strong, non-oxidizing, and biodegradable, indicating that it causes fewer environmental problems than inorganic acids. Moreover, it is an attractive alternative to organic and inorganic strong acids in various applications such as biomass valorization [58,59]. Jeong et al. [60] used $0.1 \mathrm{M}$ methanesulfonic acid to catalyze $100 \mathrm{~g} / \mathrm{L} \mathrm{GlcNH}_{2}$ at $160{ }^{\circ} \mathrm{C}$ for $40 \mathrm{~min}$, but only $2.3 \% \mathrm{HMF}$ was produced. With increasing temperature, the HMF yield continued to decrease, because $\mathrm{GlcNH}_{2}$ was converted to HMF and further hydrolyzed to LA. They also used $2 \%$ chitosan as a substrate under the same catalytic conditions at $200{ }^{\circ} \mathrm{C}$ for $15 \mathrm{~min}$, and the HMF yield reached 15.0\% [61] which far exceeded the yield in their previous study. This further validated the above hypothesis that the small molecular weight and simple structure of $\mathrm{GlcNH}_{2}$ make it easier to convert it to LA than chitosan. Therefore, the type and concentration of the substrates should be carefully selected to improve the HMF yield. According to the substrates, the chitin biomass pretreatment method should also be carefully chosen.

Savitri et al. [62] introduced ultrasound-assisted technology to the acetic-acid-catalyzed reaction system, and all of the partially dissolved chitosan was dissolved in the acetic acid solution. After chitosan was sonicated at $40{ }^{\circ} \mathrm{C}$ for $30 \mathrm{~min}$ in low concentration $(0.5 \% v / v)$ acetic acid solution, a higher concentration of HMF was detected in the soluble chitosan component. However, under the same 
conditions, chitosan degraded to $\mathrm{GlcNH}_{2}$ as the main product in high concentration acetic acid solution $(1 \% v / v)$. Therefore, the catalyst concentration is also a critical factor in conversion of chitin biomass to HMF.

Although Brønsted acids have the advantages of large output and simple operation, the use of a high concentration of a corrosive acid (e.g., $\mathrm{HCl}$ and $\mathrm{H}_{2} \mathrm{SO}_{4}$ ) will seriously corrode the reaction equipment, pollute the environment, and increase the possibility of by-product formation. This makes separation of the target product difficult and high-value conversion of chitin biomass tedious and expensive. Although organic Brønsted acids are less corrosive, they are slightly toxic which also limits development and research of organic Brønsted acid catalysts to a certain extent. Therefore, selecting an efficient catalytic system and optimizing the reaction conditions to improve the HMF yield still require more in-depth research.

\subsection{HMF Production from Chitin Biomass by Lewis Acids}

Conversion of chitin biomass to HMF by Brønsted acids has some disadvantages such as complex post-treatment, low target product yield, and intractable pollution. Therefore, an efficient catalytic system for degradation of chitin biomass is urgently required. Lewis acids are substances, including ions, radicals, and molecules, that can accept electron pairs. Compared with Brønsted acids, Lewis acids have more obvious advantages, such as low cost and high catalytic activity. Therefore, the process of Lewis acid (represented by metal chlorides) catalyzed degradation of chitin biomass to HMF has been intensively investigated.

Omari et al. [55] found that Lewis acids have higher catalytic efficiency than Brønsted acids. Among the Lewis acids investigated, $\mathrm{SnCl}_{4} \cdot 5 \mathrm{H}_{2} \mathrm{O}$ showed the best catalytic effect. When chitosan was heated at $200{ }^{\circ} \mathrm{C}$ under microwave radiation for $30 \mathrm{~min}$ with a low concentration of $\mathrm{SnCl}_{4} \cdot 5 \mathrm{H}_{2} \mathrm{O}, 10.0 \%$ $\mathrm{HMF}$ was obtained. When chitosan was similarly treated with a higher concentration of $\mathrm{SnCl}_{4} \cdot 5 \mathrm{H}_{2} \mathrm{O}_{\text {, }}$ no HMF was produced, but up to $12.7 \%$ LA was obtained. It is possible that high catalyst loading not only accelerates conversion of chitosan to $\mathrm{HMF}$, but it also promotes other side reactions, such as rehydration of HMF to LA and cross-polymerization reactions, which lower the HMF yield. Therefore, a suitable catalyst concentration should be chosen to effectively increase the target product yield. Compared with traditional heating, microwave heating has the advantages of fast heating, uniform heating, and short reaction time. Therefore, microwave heating has been applied to obtain HMF (traditional heating does not generate HMF). However, the HMF yield was still low and needs to be further optimized by changing the metal salt type.

Deng et al. [63] found that concentrated $\mathrm{ZnCl}_{2}$ solution not only dissolves lignocellulose, but it also shows a good catalytic effect for degradation in lignocellulosic biomass hydrolysis. Incompletely coordinated $\mathrm{Zn}^{2+}$ can coordinate with the $-\mathrm{OH}$ groups of carbohydrates (e.g., cellulose), thereby catalytically converting them to fructose and then to HMF. Based on the structural similarity of cellulose and chitin, there is also a strong interaction between $\mathrm{Zn}^{2+}$ and the $-\mathrm{OH},-\mathrm{NH}_{2}$, and/or -NHAc groups in chitin biomass [64,65]. Owing to protonation of these groups, the solubility of chitin biomass in concentrated $\mathrm{ZnCl}_{2}$ solution greatly increases. Wang et al. [66] used 67\% concentrated $\mathrm{ZnCl}_{2}$ solution to catalyze $\mathrm{GlcNH}_{2}$ conversion at $120{ }^{\circ} \mathrm{C}$ for $90 \mathrm{~min}$, and they obtained $21.9 \mathrm{~mol} \%$ $\mathrm{HMF}$. Therefore, concentrated $\mathrm{ZnCl}_{2}$ solution is an environmentally friendly and inexpensive chitin biotransformation medium.

There are clear differences in the catalytic effects of metal salts with different metal ions. Yu et al. [67] investigated the effects of 16 different metal salt catalysts on conversion of chitosan and GlcNAc to $\mathrm{HMF}$, including $\mathrm{AlCl}_{3}, \mathrm{MgCl}_{2}, \mathrm{FeCl}_{2}, \mathrm{FeSO}_{4}$, and the abovementioned $\mathrm{ZnCl}_{2}$ and $\mathrm{SnCl}_{4}$. Among these catalysts, $\mathrm{FeSO}_{4} \cdot 7 \mathrm{H}_{2} \mathrm{O}(22.8 \mathrm{~mol} \%)$ and $\mathrm{FeCl}_{2} \cdot 4 \mathrm{H}_{2} \mathrm{O}(33.9 \mathrm{~mol} \%)$ showed high catalytic activity in conversion of GlcNAc to HMF. Reacting chitosan in dimethyl sulfoxide (DMSO)-water-mixed solvent at $190{ }^{\circ} \mathrm{C}$ in $\mathrm{FeCl}_{2} \cdot 4 \mathrm{H}_{2} \mathrm{O}$ for $6 \mathrm{~h}$ gave an $\mathrm{HMF}$ yield of $26.6 \mathrm{~mol} \%$. This high yield is caused by the excellent solubility and long reaction time of the DMSO-water-mixed solvent. The use of a suitable 
solvent with the catalyst enables the catalyst to better dissolve in the solvent, thereby improving the HMF yield.

Sulfamic acid $\left(\mathrm{NH}_{2} \mathrm{SO}_{3} \mathrm{H}\right)$ has a tautomeric structure with Brønsted acid and Lewis acid sites. As a dual catalyst, it has unique catalytic properties and inherent zwitterionic properties. Therefore, it is often used as a substitute for conventional acid catalysts to discover new chemical reactions and processes [68]. Some studies have used $\mathrm{NH}_{2} \mathrm{SO}_{3} \mathrm{H}$ to catalyze degradation of lignocellulose [69], and Jeong et al. [70] successfully applied $\mathrm{NH}_{2} \mathrm{SO}_{3} \mathrm{H}$ to chitin biomass conversion to $\mathrm{HMF}$ for the first time. They used $0.7 \mathrm{M} \mathrm{NH}_{2} \mathrm{SO}_{3} \mathrm{H}$ to catalyze $3 \%(w / w)$ chitosan conversion at $200{ }^{\circ} \mathrm{C}$, achieving a high yield of $21.5 \%$ in $2 \mathrm{~min}$. Compared with previous studies, higher HMF yields were achieved in a much shorter reaction time, showing the extraordinary catalytic effect of $\mathrm{NH}_{2} \mathrm{SO}_{3} \mathrm{H}$.

The common disadvantages of homogeneous acid-base catalysts are many by-products, severe equipment corrosion, and complex post-treatment processes. Heterogeneous acid catalysts, also known as solid acid catalysts, are compounds with catalytically active acidic sites on the solid surface. They are easy to separate and recover from the product and can be easily recycled. They are also environmentally friendly and only slightly damage the reactor. Many homogeneous acid-base catalysts have been gradually replaced by solid acid-base catalysts. Solid acid-base catalysts are an important direction for future catalytic development. When designing a solid acid catalyst, the number of strong acid sites needs to be optimized to improve the catalytic activity which is beneficial for production of HMF. In addition, the type of acid sites in the solid acid catalyst is also an important factor that determines the reaction pathway. Common solid acid catalysts include carbon-based solid acids, molecular sieves, ion-exchange resins, and heteropoly acids [71]. Degradation of monosaccharide, starch, cellulose, and other biomasses to HMF using solid acid catalysts has been investigated (Table 2) [72-76], but degradation of chitin biomass using solid acid catalysts has rarely been reported. Kalane et al. [77] combined a solid acid catalyst with different concentrations of acetic acid to catalyze chitosan conversion to HMF by "green" synthesis. The H-zeolite catalyst combined with the lowest concentration of acetic acid produced the highest yield of HMF (15.3-28.2\%). There are many types of solid acids. Therefore, screening solid acid catalysts for conversion of chitin biomass to HMF is an important direction for future research.

Table 2. HMF production from biomass by acid catalysts.

\begin{tabular}{|c|c|c|c|c|}
\hline Substrates & Acid Catalyst & Reaction Conditions & HMF (\%) & References \\
\hline Chitosan & $2.2 \% \mathrm{H}_{2} \mathrm{SO}_{4}$ & $174^{\circ} \mathrm{C}, 36.9 \mathrm{~min}$ & 12.1 (wt.) & [56] \\
\hline $\mathrm{GlcNH}_{2}$ & $3 \% \mathrm{H}_{2} \mathrm{SO}_{4}$ & $175^{\circ} \mathrm{C}, 5 \mathrm{~min}$ & 1.8 (wt.) & [57] \\
\hline $\mathrm{GlcNH}_{2}$ & $0.1 \mathrm{M}$ MSA & $160^{\circ} \mathrm{C}, 40 \mathrm{~min}$ & 2.3 (wt.) & [60] \\
\hline Chitosan & $0.1 \mathrm{M}$ MSA & $200{ }^{\circ} \mathrm{C}, 15 \mathrm{~min}$ & 15.0 (wt.) & [61] \\
\hline Chitosan & $0.12 \mathrm{mmol} \mathrm{SnCl}_{4} \cdot 5 \mathrm{H}_{2} \mathrm{O}$ & $\mathrm{MW} 200^{\circ} \mathrm{C}, 30 \mathrm{~min}$ & 10.0 (wt.) & [55] \\
\hline $\mathrm{GlcNH}_{2}$ & $67 \% \mathrm{ZnCl}_{2}$ & $120^{\circ} \mathrm{C}, 90 \mathrm{~min}$ & $21.9(\mathrm{~mol})$ & [66] \\
\hline GlcNAc & $\mathrm{FeCl}_{2} \cdot 4 \mathrm{H}_{2} \mathrm{O}$ & $190^{\circ} \mathrm{C}, 6 \mathrm{~h}$ & $33.9(\mathrm{~mol})$ & {$[67]$} \\
\hline Chitosan & $\mathrm{FeCl}_{2} \cdot 4 \mathrm{H}_{2} \mathrm{O}$ & DMSO-water solvent & $26.6(\mathrm{~mol})$ & [67] \\
\hline Chitosan & $0.7 \mathrm{M} \mathrm{NH}_{2} \mathrm{SO}_{3} \mathrm{H}$ & $200{ }^{\circ} \mathrm{C}, 2 \mathrm{~min}$ & 21.5 (wt.) & [70] \\
\hline
\end{tabular}

\subsection{HMF Production from Chitin Biomass Using ILs}

In addition to the catalyst, the solvent is also crucial for degradation of chitin biomass. The solvent can not only dissolve the substrate and catalyst to promote the reaction, but it can also stabilize the thermodynamic equilibrium of the substrate, intermediates, and products to obtain a high product yield and be used as a catalyst to improve the reaction kinetics. Iion liquids have attracted widespread attention as new environmentally friendly "green solvents". They have many advantages such as good stability, low melting point, low vapor pressure, adjustable acidity, good density, viscosity, solubility, and recyclability. They can be used as a solvent and a catalyst in the biomass conversion process to participate in chemical reactions, and they have the advantages of high conversion rate and good selectivity. They are widely used in chemical extraction and separation, organic synthesis, 
electrochemistry, nanomaterials, and other new functional materials, and they are becoming one of the most promising reaction media and catalytic systems in green chemistry [78-80].

A lot of studies have reported the excellent performance of ILs in catalyzing degradation of cellulose biomass or monosaccharides to produce HMF [80-83]. Use of IL catalytic systems to degrade chitin biomass has also attracted interest. By introducing different functional groups to the anions and cations, different functionalized ILs have been designed to optimize the catalytic effect. Investigating the reaction conditions is also crucial to optimize the HMF yield from chitin biomass.

In recent years, considerable effort has been devoted to catalytic degradation of chitin biomass in ILs. Feng et al. [84] used 3-methyl-1-butylimidazole hydrogen sulfate IL as the catalyst and $\mathrm{AlCl}_{3} \cdot 6 \mathrm{H}_{2} \mathrm{O}$ as a cocatalyst for catalytic degradation of chitosan at $180^{\circ} \mathrm{C}$ for $5 \mathrm{~h}$, and they achieved a HMF yield of $25.2 \mathrm{~mol} \%$, providing the concept of synergistic catalytic degradation of chitin biomass by Lewis acids and ILs. Li et al. [85] chose nine types of acidic ILs with different anions and cations for catalytic degradation of chitosan, and $\mathrm{N}$-methylimidazole hydrogen sulfate ([MIM] $\left.\mathrm{HSO}_{4}\right) \mathrm{IL}_{\text {showed the best }}$ catalytic effect. They also found that the acidity, hydrogen bonding ability, and steric hindrance of the IL affected the reaction. Using [MIM] $\mathrm{HSO}_{4}$ as a catalyst to catalyze conversion of chitosan and chitin at $180^{\circ} \mathrm{C}$ for $5 \mathrm{~h}$, they achieved HMF yields of 29.5 and $19.3 \mathrm{~mol} \%$, respectively. However, they believed that the highest HMF yield for chitin conversion of $19.3 \mathrm{~mol} \%$ was still low. Further research is therefore required to develop an efficient and economically feasible HMF production process from chitin biomass. Zang et al. (Table 3) [86] found that methyl imidazole hydrogen sulfate ([Hmim] $\left.\left[\mathrm{HSO}_{4}\right]\right)$ IL showed the best catalytic performance for chitosan conversion at $180^{\circ} \mathrm{C}$ for $6 \mathrm{~h}$ in DMSO-water-mixed solvent among seven acidic ILs, with a HMF yield of $34.7 \mathrm{~mol} \%$. The catalytic effect of ILs has been improved by improving the type of IL. To achieve conversion of chitin biomass to HMF under mild conditions, Zhang et al. [87] used benzimidazole chloride ([Hbim]Cl) IL to degrade chitosan at $180{ }^{\circ} \mathrm{C}$ for $3 \mathrm{~h}$ in $10 \mathrm{wt} \%$ DMSO-water-mixed solvent. They achieved a highest HMF yield of $34.9 \%$, while the HMF yield in the pure water system was $30.8 \mathrm{~mol} \%$. It is clear that the type of IL and the choice of DMSO solvent are significant. Owing to the improved catalytic effect of ILs, the reaction time to achieve the same HMF yield was reduced by half $(3 \mathrm{~h})$ compared with the reaction in the pure water system $(6 \mathrm{~h})$. This indicates that $[\mathrm{Hbim}] \mathrm{Cl}$ is an efficient, sustainable, and environmentally friendly catalyst for conversion of chitin biomass to high value-added chemicals. Additionally, as environmentally friendly catalysts, Brønsted-Lewis acidic ILs have also attracted attention, because they combine the characteristics of Brønsted-Lewis solid acids and ILs. Jiang et al. [88] were the first to use a Brønsted-Lewis acidic IL ([Hmim] $\left[\mathrm{HSO}_{4}\right]-0.5 \mathrm{FeCl}_{2}$ ) to degrade chitosan to HMF. After reaction of chitosan at $180^{\circ} \mathrm{C}$ for $4 \mathrm{~h}$ under hydrothermal conditions, the HMF yield was $44.1 \mathrm{~mol} \%$. They believed that these research achievements will benefit the economy and environment. Therefore, development of new low cost and high activity functionalized ILs is one of the main directions in this field. In addition, new functionalized ILs can also work synergistically with catalysts, such as Lewis acids, to combine their respective advantages.

Table 3. HMF production from biomass using ILs.

\begin{tabular}{ccccc}
\hline Substrates & ILs & Reaction Conditions & HMF (\%) & References \\
\hline Chitosan & {$\left[{\mathrm{BMIM}] \mathrm{HSO}_{4}}\right.$} & $180{ }^{\circ} \mathrm{C}, 5 \mathrm{~h}$ & $25.2(\mathrm{~mol})$ & {$[84]$} \\
Chitosan & {$[\mathrm{MIM}] \mathrm{HSO}_{4}$} & $180{ }^{\circ} \mathrm{C}, 5 \mathrm{~h}$ & $29.5(\mathrm{~mol})$ & {$[85]$} \\
Chitin & & $180^{\circ} \mathrm{C}, 6 \mathrm{~h}$ & $19.3(\mathrm{~mol})$ & $25.7(\mathrm{~mol})$ \\
Chitin & & DMSO-water solvent & $34.7(\mathrm{~mol})$ & {$[86]$} \\
Chitosan & {$\left[[\mathrm{Hmim}]\left[\mathrm{HSO}_{4}\right]\right]$} & $180^{\circ} \mathrm{C}, 6 \mathrm{~h}$ & $30.8(\mathrm{~mol})$ & \\
Chitosan & & $180^{\circ} \mathrm{C}, 3 \mathrm{~h}$ & $34.9(\mathrm{~mol})$ & {$[87]$} \\
Chitosan & {$[\mathrm{Hbim}] \mathrm{Cl}$} & DMSO-water solvent & $44.1(\mathrm{~mol})$ & {$[88]$} \\
Chitosan & {$[\mathrm{Hmim}]\left[\mathrm{HSO}_{4}\right]-0.5 \mathrm{FeCl}_{2}$} & $180^{\circ} \mathrm{C}, 4 \mathrm{~h}$ & 4 \\
\hline
\end{tabular}




\section{Conclusions}

In recent years, to reduce the dependence on traditional fossil resources in the chemical industry, attention has turned to renewable biomass resources with high annual output. Preparation of fuels and precursor compounds from biomass has attracted widespread attention. Chitin biomass is the second largest natural renewable biomass resource after cellulose. Conversion of chitin biomass to HMF has great application prospects. However, degradation of chitin biomass is a very complicated multi-step reaction process with many side reactions, heterogeneous products, and difficult separation. Conversion of chitin biomass to HMF still faces many problems. In future research, researchers should focus on the following aspects:

(1) Selection of green and feasible pretreatment methods during biomass conversion. Through selection and combination of suitable pretreatment methods, an efficient and green pretreatment extraction process for chitin and/or chitosan should be developed to realize the possibility of chitin biomass conversion to HMF;

(2) New, highly selective, highly active, and green catalytic solvent systems should be designed to develop green and efficient catalytic systems. The synergistic catalytic effect of different catalysts should also be explored to improve the targeted conversion efficiency of HMF;

(3) The mechanism of HMF conversion should be deeply investigated, and the reaction conditions should be optimized to improve the HMF yield.

Author Contributions: Conceptualization, D.Z., D.S. and Y.L.; Writing-Original Draft Preparation, D.Z.; Writing-Review and Editing, W.L., T.S. and Y.L.; Writing-Review and Comments, M.W., H.F. and J.S.; Funding acquisition, Y.L. and D.S.; Drawing diagrams, D.Z. All authors have read and agreed to the published version of the manuscript.

Funding: This work was supported by the National Natural Science Foundation of China (grant no.41977331 and no.51778579) and the Zhejiang Xinmiao Talents Program (2019R40858). We thank Tim Cooper, Liwen Bianji, Edanz Editing China (www.liwenbianji.cn/ac), for editing the English text of a draft of this manuscript.

Conflicts of Interest: The authors declare no conflict of interest.

\section{Abbreviation}

The following abbreviations are used in this manuscript:

$\begin{array}{ll}\text { DD } & \text { degree of deacetylation } \\ \text { DES } & \text { deep eutectic solvent } \\ \text { DMSO } & \text { dimethyl sulfoxide } \\ \text { GlcNAc } & N \text {-acetylglucosamine } \\ \text { GlcNH} & \text { glucosamine } \\ \mathrm{HMF} & \text { 5-hydroxymethylfurfural } \\ {\left[[\mathrm{Hmim}]\left[\mathrm{HSO}_{4}\right]\right]} & \text { methyl imidazole hydrogen sulfate } \\ {[\mathrm{Hbim}] \mathrm{Cl}} & \text { benzimidazole chloride } \\ \mathrm{IL} & \text { ionic liquid } \\ \mathrm{LA} & \text { levulinic acid } \\ {[\mathrm{MIM}] \mathrm{HSO}_{4}} & \text { N-methylimidazole hydrogen sulfate } \\ \mathrm{NADES} & \text { natural deep eutectic solvent } \\ \mathrm{NH}_{2} \mathrm{SO}_{3} \mathrm{H} & \text { sulfamic acid }\end{array}$

\section{References}

1. Zhao, H.; Holladay, J.E.; Brown, H.; Zhang, Z.C. Metal Chlorides in Ionic Liquid Solvents Convert Sugars to 5-Hydroxymethylfurfural. Science 2007, 316, 1597-1600. [CrossRef]

2. Menegazzo, F.; Ghedini, E.; Signoretto, M. 5-Hydroxymethylfurfural (HMF) Production from Real Biomasses. Molecules 2018, 23, 2201. [CrossRef] [PubMed]

3. Chen, X.; Zhang, B.; Wang, Y.; Yan, N. Valorization of Renewable Carbon Resources for Chemicals. CHIMIA Int. J. Chem. 2014, 69, 120-124. [CrossRef] [PubMed] 
4. Kang, S.; Fu, J.; Zhang, G. From lignocellulosic biomass to levulinic acid: A review on acid-catalyzed hydrolysis. Renew. Sustain. Energy Rev. 2018, 94, 340-362. [CrossRef]

5. Delbecq, F.; Len, C. Recent Advances in the Microwave-Assisted Production of Hydroxymethylfurfural by Hydrolysis of Cellulose Derivatives-A Review. Molecules 2018, 23, 1973. [CrossRef]

6. Yan, N.; Chen, X. Sustainability: Don't waste seafood waste. Nat. News 2015, 524, 155. [CrossRef]

7. Kerton, F.M.; Liu, Y.; Omari, K.W.; Hawboldt, K. Green chemistry and the ocean-based biorefinery. Green Chem. 2013, 15, 860-871. [CrossRef]

8. Xi, C.; Ning, Y. Novel Catalytic Systems to Convert Chitin and Lignin into Valuable Chemicals. Catal. Surv. Asia 2014, 18, 164-176.

9. Chen, X.; Yang, H.; Yan, N. Shell Biorefinery: Dream or Reality? Chem. Eur. J. 2016, 22, $13402-13421$. [CrossRef]

10. Bozell, J.J.; Petersen, G.R. Technology development for the production of biobased products from biorefinery carbohydrates-the US Department of Energy's "Top 10" revisited. Green Chem. 2010, 12, 539-554. [CrossRef]

11. Zhang, M.; Zang, H.; Yu, S.; Yan, B. Advances in conversion of chitin biomass into high-value chemicals. Chem. Ind. Eng. Prog. 2017, 36, 863-872, (In Chinese with English Abtract).

12. Nikolov, S.; Petrov, M.; Lymperakis, L.; Friak, M.; Sachs, C.; Fabritius, H.-O.; Raabe, D.; Neugebauer, J. Revealing the Design Principles of High-Performance Biological Composites Using Ab initio and Multiscale Simulations: The Example of Lobster Cuticle. Adv. Mater. 2010, 22, 519-526. [CrossRef] [PubMed]

13. Wang, Y.; Chang, Y.; Yu, L.; Zhang, C.; Xu, X.; Xue, Y.; Li, Z.; Xue, C. Crystalline structure and thermal property characterization of chitin from Antarctic krill (Euphausia superba). Carbohydr. Polym. 2013, 92, 90-97. [CrossRef] [PubMed]

14. Srinivasan, H.; Velayutham, K.; Ravichandran, R. Chitin and chitosan preparation from shrimp shells Penaeus monodon and its human ovarian cancer cell line, PA-1. Int. J. Biol. Macromol. 2018, 107, 662-667. [CrossRef] [PubMed]

15. Younes, I.; Hajji, S.; Frachet, V.; Rinaudo, M.; Jellouli, K.; Nasri, M. Chitin extraction from shrimp shell using enzymatic treatment. Antitumor, antioxidant and antimicrobial activities of chitosan. Int. J. Biol. Macromol. 2014, 69, 489-498. [CrossRef] [PubMed]

16. Zhang, A.; Wei, G.; Mo, X.; Zhou, N.; Chen, K.; Ouyang, P. Enzymatic hydrolysis of chitin pretreated by bacterial fermentation to obtain pure N-acetyl-D-glucosamine. Green Chem. 2018, 20, 2320-2327. [CrossRef]

17. Pacheco, N.; Garnica-Gonzalez, M.; Gimeno, M.; Barzana, E.; Trombotto, S.; David, L.; Shirai, K. Structural Characterization of Chitin and Chitosan Obtained by Biological and Chemical Methods. Biomacromolecules 2011, 12, 3285-3290. [CrossRef]

18. Setoguchi, T.; Kato, T.; Yamamoto, K.; Kadokawa, J.-i. Facile production of chitin from crab shells using ionic liquid and citric acid. Int. J. Biol. Macromol. 2012, 50, 861-864. [CrossRef]

19. Barber, P.S.; Griggs, C.S.; Bonner, J.R.; Rogers, R.D. Electrospinning of chitin nanofibers directly from an ionic liquid extract of shrimp shells. Green Chem. 2013, 15, 601-607. [CrossRef]

20. Qin, Y.; Lu, X.; Sun, N.; Rogers, R.D. Dissolution or extraction of crustacean shells using ionic liquids to obtain high molecular weight purified chitin and direct production of chitin films and fibers. Green Chem. 2010, 12, 968-971. [CrossRef]

21. Ishii, D.; Ohashi, C.; Hayashi, H. Facile enhancement of the deacetylation degree of chitosan by hydrothermal treatment in an imidazolium-based ionic liquid. Green Chem. 2014, 16, 1764-1767. [CrossRef]

22. Paiva, A.; Craveiro, R.; Aroso, I.; Martins, M.; Reis, R.L.; Duarte, A.R.C. Natural Deep Eutectic Solvents-Solvents for the 21st Century. ACS Sustain. Chem. Eng. 2014, 2, 1063-1071. [CrossRef]

23. Pinkert, A.; Marsh, K.N.; Pang, S.; Staiger, M.P. Ionic Liquids and Their Interaction with Cellulose. Chem. Rev. 2009, 109, 6712-6728. [CrossRef] [PubMed]

24. del Monte, F.; Carriazo, D.; Serrano, M.C.; Gutierrez, M.C.; Ferrer, M.L. Deep Eutectic Solvents in Polymerizations: A Greener Alternative to Conventional Syntheses. Chemsuschem 2014, 7, 999-1009. [CrossRef]

25. Abbott, A.P.; Boothby, D.; Capper, G.; Davies, D.L.; Rasheed, R.K. Deep Eutectic Solvents Formed between Choline Chloride and Carboxylic Acids: Versatile Alternatives to Ionic Liquids. J. Am. Chem. Soc. 2004, 126, 9142-9147. [CrossRef]

26. Zhang, Q.; Vigier, K.D.O.; Royer, S.; Jerome, F. Deep eutectic solvents: syntheses, properties and applications. Chem. Soc. Rev. 2012, 41, 7108-7146. [CrossRef] 
27. Zhu, P.; Gu, Z.; Hong, S.; Lian, H. One-pot production of chitin with high purity from lobster shells using choline chloride-malonic acid deep eutectic solvent. Carbohydr. Polym. 2017, 177, 217-223. [CrossRef]

28. Hong, S.; Yuan, Y.; Yang, Q.; Zhu, P.; Lian, H. Versatile acid base sustainable solvent for fast extraction of various molecular weight chitin from lobster shell. Carbohydr. Polym. 2018, 201, 211-217. [CrossRef]

29. Huang, W.-C.; Zhao, D.; Guo, N.; Xue, C.; Mao, X. Green and Facile Production of Chitin from Crustacean Shells Using a Natural Deep Eutectic Solvent. J. Agric. Food. Chem. 2018, 66, 11897-11901. [CrossRef]

30. Tan, Y.T.; Chua, A.S.M.; Ngoh, G.C. Deep eutectic solvent for lignocellulosic biomass fractionation and the subsequent conversion to bio-based products-A review. Bioresour. Technol. 2019, 122522. [CrossRef]

31. Zhang, J.; Feng, M.; Lu, X.; Shi, C.; Li, X.; Xin, J.; Yue, G.; Zhang, S. Base-free preparation of low molecular weight chitin from crab shell. Carbohydr. Polym. 2018, 190, 148-155. [CrossRef] [PubMed]

32. Hong, S.; Yang, Q.; Yuan, Y.; Chen, L.; Song, Y.; Lian, H. Sustainable co-solvent induced one step extraction of low molecular weight chitin with high purity from raw lobster shell. Carbohydr. Polym. 2019, 205, 236-243. [CrossRef] [PubMed]

33. Devi, R.; Dhamodharan, R. Pretreatment in Hot Glycerol for Facile and Green Separation of Chitin from Prawn Shell Waste. ACS Sustain. Chem. Eng. 2017, 6, 846-853. [CrossRef]

34. Liu, C.; Wang, G.; Sui, W.; An, L.; Si, C. Preparation and Characterization of Chitosan by a Novel Deacetylation Approach Using Glycerol as Green Reaction Solvent. ACS Sustain. Chem. Eng. 2017, 5, 4690-4698. [CrossRef]

35. Yang, H.; Gozaydin, G.; Nasaruddin, R.R.; Har, J.R.G.; Chen, X.; Wang, X.; Yan, N. Toward the Shell Biorefinery: Processing Crustacean Shell Waste Using Hot Water and Carbonic Acid. ACS Sustain. Chem. Eng. 2019, 7, 5532-5542. [CrossRef]

36. Vasil'eva, T.M.; Lopatin, S.A.; Varlamov, V.P. Production of the low-molecular-weight chitin and chitosan forms in electron-beam plasma. High Energy Chem. 2016, 50, 150-154. [CrossRef]

37. Birolli, W.G.; de Moura Delezuk, J.A.; Campana-Filho, S.P. Ultrasound-assisted conversion of alpha-chitin into chitosan. Appl. Acoust. 2016, 103, 239-242. [CrossRef]

38. Fiamingo, A.; de Moura Delezuk, J.A.; Trombotto, S.; David, L.; Campana-Filho, S.P. Extensively deacetylated high molecular weight chitosan from the multistep ultrasound-assisted deacetylation of beta-chitin. Ultrason. Sonochem. 2016, 32, 79-85. [CrossRef]

39. Wu, T.; Wu, C.; Xiang, Y.; Huang, J.; Luan, L.; Chen, S.; Hu, Y. Kinetics and mechanism of degradation of chitosan by combining sonolysis with $\mathrm{H}_{2} \mathrm{O}_{2}$ /ascorbic acid. RSC Adv. 2016, 6, 76280-76287. [CrossRef]

40. Rathi, A.K.; Gawande, M.B.; Zboril, R.; Varma, R.S. Microwave-assisted synthesis-Catalytic applications in aqueous media. Coord. Chem. Rev. 2015, 291, 68-94. [CrossRef]

41. Yang, G.; Park, S.-J. Author Response to Comment on: Conventional and Microwave Hydrothermal Synthesis and Application of Functional Materials: A Review. Materials 2019, 12, 3640. [CrossRef] [PubMed]

42. Sahu, A.; Goswami, P.; Bora, U. Microwave mediated rapid synthesis of chitosan. J. Mater. Sci. Mater. Med. 2009, 20, 171-175. [CrossRef] [PubMed]

43. Samar, M.M.; El-Kalyoubi, M.H.; Khalaf, M.M.; El-Razik, M.M.A. Physicochemical, functional, antioxidant and antibacterial properties of chitosan extracted from shrimp wastes by microwave technique. Ann. Agric. Sci. 2013, 58, 33-41. [CrossRef]

44. El Knidri, H.; Dahmani, J.; Addaou, A.; Laajeb, A.; Lahsini, A. Rapid and efficient extraction of chitin and chitosan for scale-up production: Effect of process parameters on deacetylation degree and molecular weight. Int. J. Biol. Macromol. 2019, 139, 1092-1102. [CrossRef] [PubMed]

45. Al Sagheer, F.A.; Al-Sughayer, M.A.; Muslim, S.; Elsabee, M.Z. Extraction and characterization of chitin and chitosan from marine sources in Arabian Gulf. Carbohydr. Polym. 2009, 77, 410-419. [CrossRef]

46. El Knidri, H.; El Khalfaouy, R.; Laajeb, A.; Addaou, A.; Lahsini, A. Eco-friendly extraction and characterization of chitin and chitosan from the shrimp shell waste via microwave irradiation. Process Saf. Environ. Prot. 2016, 104, 395-405. [CrossRef]

47. Kleine, T.; Buendia, J.; Bolm, C. Mechanochemical degradation of lignin and wood by solvent-free grinding in a reactive medium. Green Chem. 2013, 15, 160-166. [CrossRef]

48. Di Nardo, T.; Hadad, C.; Van Nhien, A.N.; Moores, A. Synthesis of high molecular weight chitosan from chitin by mechanochemistry and aging. Green Chem. 2019, 21, 3271-3285. [CrossRef]

49. Margoutidis, G.; Parsons, V.H.; Bottaro, C.S.; Yan, N.; Kerton, F.M. Mechanochemical Amorphization of alpha-Chitin and Conversion into Oligomers of N-Acetyl-D-glucosamine. ACS Sustain. Chem. Eng. 2018, 6, 1662-1669. [CrossRef] 
50. Chen, X.; Yang, H.; Zhong, Z.; Yan, N. Base-catalysed, one-step mechanochemical conversion of chitin and shrimp shells into low molecular weight chitosan. Green Chem. 2017, 19, 2783-2792. [CrossRef]

51. Zhao, D.; Huang, W.-C.; Guo, N.; Zhang, S.; Xue, C.; Mao, X. Two-Step Separation of Chitin from Shrimp Shells Using Citric Acid and Deep Eutectic Solvents with the Assistance of Microwave. Polymers 2019, 11, 409. [CrossRef] [PubMed]

52. Vlachos, D.G.; Caratzoulas, S. The roles of catalysis and reaction engineering in overcoming the energy and the environment crisis. Chem. Eng. Sci. 2010, 65, 18-29. [CrossRef]

53. Yu, I.K.M.; Tsang, D.C.W. Conversion of biomass to hydroxymethylfurfural: A review of catalytic systems and underlying mechanisms. Bioresour. Technol. 2017, 238, 716-732. [CrossRef] [PubMed]

54. Wettstein, S.G.; Alonso, D.M.; Guerbuez, E.I.; Dumesic, J.A. A roadmap for conversion of lignocellulosic biomass to chemicals and fuels. Curr. Opin. Chem. Eng. 2012, 1, 218-224. [CrossRef]

55. Omari, K.W.; Besaw, J.E.; Kerton, F.M. Hydrolysis of chitosan to yield levulinic acid and 5-hydroxymethylfurfural in water under microwave irradiation. Green Chem. 2012, 14, 1480-1487. [CrossRef]

56. Lee, S.-B.; Jeong, G.-T. Catalytic Conversion of Chitosan to 5-Hydroxymethylfurfural Under Low Temperature Hydrothermal Process. Appl. Biochem. Biotechnol. 2015, 176, 1151-1161. [CrossRef]

57. Jeong, G.-T. Production of levulinic acid from glucosamine by dilute-acid catalyzed hydrothermal process. Ind. Crops Prod. 2014, 62, 77-83. [CrossRef]

58. Rackemann, D.W.; Bartley, J.P.; Doherty, W.O.S. Methanesulfonic acid-catalyzed conversion of glucose and xylose mixtures to levulinic acid and furfural. Ind. Crops Prod. 2014, 52, 46-57. [CrossRef]

59. Rackemann, D.W.; Bartley, J.P.; Harrison, M.D.; Doherty, W.O.S. The effect of pretreatment on methanesulfonic acid-catalyzed hydrolysis of bagasse to levulinic acid, formic acid, and furfural. RSC Adv. 2016, 6, 74525-74535. [CrossRef]

60. Park, M.-R.; Kim, H.S.; Kim, S.-K.; Jeong, G.-T. Thermo-chemical conversion for production of levulinic and formic acids from glucosamine. Fuel Process. Technol. 2018, 172, 115-124. [CrossRef]

61. Kim, H.S.; Park, M.-R.; Kim, S.-K.; Jeong, G.-T. Valorization of chitosan into levulinic acid by hydrothermal catalytic conversion with methanesulfonic acid. Korean J. Chem. Eng. 2018, 35, 1290-1296. [CrossRef]

62. Savitri, E.; Juliastuti, R.; Handaratri, A.; Sumarno; Roesyadi, A. Degradation of chitosan by sonication in very-low-concentration acetic acid. Polym. Degrad. Stab. 2014, 110, 344-352. [CrossRef]

63. Deng, T.; Cui, X.; Qi, Y.; Wang, Y.; Hou, X.; Zhu, Y. Conversion of carbohydrates into 5-hydroxymethylfurfural catalyzed by $\mathrm{ZnCl}_{2}$ in water. Chem. Commun. 2012, 48, 5494-5496. [CrossRef] [PubMed]

64. Varma, A.J.; Deshpande, S.V.; Kennedy, J.F. Metal complexation by chitosan and its derivatives: A review. Carbohydr. Polym. 2004, 55, 77-93. [CrossRef]

65. Wang, X.; Du, Y.; Liu, H. Preparation, characterization and antimicrobial activity of chitosan-Zn complex. Carbohydr. Polym. 2004, 56, 21-26. [CrossRef]

66. Wang, Y.; Pedersen, C.M.; Deng, T.; Qiao, Y.; Hou, X. Direct conversion of chitin biomass to 5-hydroxymethylfurfural in concentrated $\mathrm{ZnCl}_{2}$ aqueous solution. Bioresour. Technol. 2013, 143, 384-390. [CrossRef]

67. Yu, S.; Zang, H.; Chen, S.; Jiang, Y.; Yan, B.; Cheng, B. Efficient conversion of chitin biomass into 5-hydroxymethylfurfural over metal salts catalysts in dimethyl sulfoxide -water mixture under hydrothermal conditions. Polym. Degrad. Stab. 2016, 134, 105-114. [CrossRef]

68. Rostami, A.; Yari, A. Sulfamic acid as a recyclable and green catalyst for rapid and highly efficient synthesis of 2-arylbenzothiazoles in water at room temperature. J. Iran. Chem. Soc. 2012, 9, 489-493. [CrossRef]

69. Sun, J.; Yuan, X.; Shen, Y.; Yi, Y.; Wang, B.; Xu, F.; Sun, R. Conversion of bamboo fiber into 5-hydroxymethylfurfural catalyzed by sulfamic acid with microwave assistance in biphasic system. Ind. Crops Prod. 2015, 70, 266-271. [CrossRef]

70. Kim, H.S.; Park, M.-R.; Jeon, Y.J.; Kim, S.-K.; Hong, Y.-K.; Jeong, G.-T. Valorization of Chitosan as Food Waste of Aquatic Organisms into 5-Hydroxymethylfurfural by Sulfamic Acid-Catalyzed Conversion Process. Energy Technol. 2018, 6, 1747-1754. [CrossRef]

71. Agarwal, B.; Kailasam, K.; Sangwan, R.S.; Elumalai, S. Traversing the history of solid catalysts for heterogeneous synthesis of 5-hydroxymethylfurfural from carbohydrate sugars: A review. Renew. Sustain. Energy Rev. 2018, 82, 2408-2425. [CrossRef] 
72. Dai, J.H.; Zhu, L.F.; Tang, D.Y.; Fu, X.; Tang, J.Q.; Guo, X.W.; Hu, C.W. Sulfonated polyaniline as a solid organocatalyst for dehydration of fructose into 5-hydroxymethylfurfural. Green Chem. 2017, 19, 1932-1939. [CrossRef]

73. Huang, F.M.; Su, Y.W.; Tao, Y.; Sun, W.; Wang, W.T. Preparation of 5-hydroxymethylfurfural from glucose catalyzed by silica-supported phosphotungstic acid heterogeneous catalyst. Fuel 2018, 226, 417-422. [CrossRef]

74. Wang, J.J.; Tan, Z.C.; Zhu, C.C.; Miao, G.; Kong, L.Z.; Sun, Y.H. One-pot catalytic conversion of microalgae (Chlorococcum sp.) into 5-hydroxymethylfurfural over the commercial H-ZSM-5 zeolite. Green Chem. 2016, 18, 452-460. [CrossRef]

75. Bhaumik, P.; Dhepe, P.L. Influence of properties of SAPO's on the one-pot conversion of mono-, di- and poly-saccharides into 5-hydroxymethylfurfural. RSC Adv. 2013, 3, 17156-17165. [CrossRef]

76. Yan, L.L.; Liu, N.A.; Wang, Y.; Machida, H.; Qi, X.H. Production of 5-hydroxymethylfurfural from corn stalk catalyzed by corn stalk-derived carbonaceous solid acid catalyst. Bioresour. Technol. 2014, 173, 462-466. [CrossRef]

77. Kalane, N.D.; Krishnan, R.A.; Yadav, V.D.; Jain, R.; Dandekar, P. Synergistic effect of hetero- and homo-catalysts on the "green' synthesis of 5-hydroxymethylfurfural from chitosan biomass. Cellulose 2019, 26, 2805-2819. [CrossRef]

78. Weerachanchai, P.; Leong, S.S.J.; Chang, M.W.; Ching, C.B.; Lee, J.M. Improvement of biomass properties by pretreatment with ionic liquids for bioconversion process. Bioresour. Technol. 2012, 111, 453-459. [CrossRef]

79. Wang, G.; Zhang, S.P.; Xu, W.J.; Qi, W.; Yan, Y.J.; Xu, Q.L. Efficient saccharification by pretreatment of bagasse pith with ionic liquid and acid solutions simultaneously. Energy Convers. Manag. 2015, 89, 120-126. [CrossRef]

80. Dutta, S.; Pal, S. Promises in direct conversion of cellulose and lignocellulosic biomass to chemicals and fuels: Combined solvent-nanocatalysis approach for biorefinary. Biomass Bioenergy 2014, 62, 182-197. [CrossRef]

81. Ramli, N.A.S.; Amin, N.A.S. Thermo-kinetic assessment of glucose decomposition to 5-hydroxymethyl furfural and levulinic acid over acidic functionalized ionic liquid. Chem. Eng. 2018, 335, 221-230. [CrossRef]

82. Li, C.Z.; Zhao, Z.B.K.; Cai, H.L.; Wang, A.Q.; Zhang, T. Microwave-promoted conversion of concentrated fructose into 5-hydroxymethylfurfural in ionic liquids in the absence of catalysts. Biomass Bioenergy 2011, 35, 2013-2017. [CrossRef]

83. Xiong, Y.; Zhang, Z.H.; Wang, X.; Liu, B.; Lin, J.T. Hydrolysis of cellulose in ionic liquids catalyzed by a magnetically-recoverable solid acid catalyst. Chem. Eng. 2014, 235, 349-355. [CrossRef]

84. Feng, J.; Zang, H.; Yan, B.; Li, M.; Cheng, B. Conversion of Chitosan into 5-Hydroxymethylfurfural via Hydrothermal Synthesis. Adv. Mater. Res. 2015, 1095, 411-414.

85. Li, M.; Zang, H.; Feng, J.; Yan, Q.; Yu, N.; Shi, X.; Cheng, B. Efficient conversion of chitosan into 5-hydroxymethylfurfural via hydrothermal synthesis in ionic liquids aqueous solution. Polym. Degrad. Stab. 2015, 121, 331-339. [CrossRef]

86. Zang, H.; Yu, S.; Yu, P.; Ding, H.; Du, Y.; Yang, Y.; Zhang, Y. Hydrothermal conversion of $\mathrm{N}$-acetyl-D-glucosamine to 5-hydroxymethylfurfural using ionic liquid as a recycled catalyst in a water-dimethyl sulfoxide mixture. Carbohydr. Res. 2017, 442, 1-8. [CrossRef]

87. Zhang, M.; Zang, H.; Ma, B.; Zhang, X.; Xie, R.; Cheng, B. Green Synthesis of 5-Hydroxymethylfurfural from Chitosan Biomass Catalyzed by Benzimidazole-Based Ionic Liquids. Chemistryselect 2017, 2, 10323-10328. [CrossRef]

88. Jiang, Y.; Zang, H.; Han, S.; Yan, B.; Yu, S.; Cheng, B. Direct conversion of chitosan to 5-hydroxymethylfurfural in water using Bronsted-Lewis acidic ionic liquids as catalysts. RSC Adv. 2016, 6, 103774-103781. [CrossRef]

Sample Availability: Samples of the compounds are not available from the authors. 